\title{
A link between vascular damage and cognitive deficits after whole-brain radiation therapy for cancer: A clue to other types of dementia?
}

\author{
Maki K. Yamada* \\ Isotope Science Center, The University of Tokyo, Tokyo, Japan.
}

\begin{abstract}
Summary Whole brain radiation therapy for the treatment of tumors can sometimes cause cognitive impairment. Memory deficits were noted in up to $\mathbf{5 0 \%}$ of treated patients over a short period of several months. In addition, an increased rate of dementia in young patients has been noted over the longer term, i.e. years. A deficit in neurogenesis after irradiation has been postulated to be the main cause of cognitive decline in patients, but recent data on irradiation therapy for limited parts of the brain appear to indicate other possibilities. Irradiation can directly damage various types of cells other than neuronal stem cells. However, this paper will focus on injury to brain vasculature leading to cognitive decline since vessels represent a better therapeutic target for drug development than other cells in the brain because of the bloodbrain barrier.
\end{abstract}

Keywords: Irradiation, angiogenesis, memory, learning, cognitive deficits, Alzheimer disease

\section{Introduction}

Whole brain radiation therapy (WBRT) is commonly used for the treatment of brain tumors and cancers with brain metastasis. Since growing cells such as tumor cells are more sensitive to irradiation than normal cells, irradiation can be used to kill the malignant cells and improve the survival rate in patients with tumors. However, cognitive impairment is a well-documented consequence of WBRT (1-4). In addition to acute encephalopathy $(5,6)$, memory deficits have been noted in up to $50 \%$ of patients undergoing WBRT over a short period of several months. In addition, WBRT is reported to increase the rate of dementia three-fold in younger patients $(<65$ years old, up to around $0.2 \%$ of irradiated persons) (7) and to lower the intelligence quotient (IQ) of children (8) over the longer term, i.e. years.

A deficit in neurogenesis has been postulated to be

Released online in J-STAGE as advance publication April 18, 2016.

*Address correspondence to:

Dr. Maki K. Yamada, Isotope Science Center, The University of Tokyo, 2-11-16, Yayoi, Bunkyo-ku, Tokyo, 113-0032, Japan. (Present address: Kagawa School of Pharmaceutical Sciences, Tokushima Bunri University, 1314-1 Shido, Sanuki city Kagawa 769-2193 Japan.)

E-mail: makiky-tky@umin.ac.jp the main cause of cognitive decline (9-11), but recent data on irradiation therapy (RT) for various parts of the brain appear to indicate the complex causes of cognitive deficits. Analysis indicated that different regions are of varying importance when performing certain cognitive tasks, suggesting that hippocampal neurogenesis alone may be an oversimplification of the brain injury processes occurring after RT (12).

Irradiation can directly damage various types of cells other than neuronal stem cells for neurogenesis (13), but the current paper will focus on injury to the brain vasculature leading to cognitive decline. This is, at least partially, because vessels represent a better therapeutic target for drug development than other cells in the brain because of the blood-brain barrier.

\section{Small blood vessels in the brain}

The brain has an elaborate vascular system. Arteries and veins are joined by a fine network of capillaries that are intertwined with the surrounding neuronal architecture $(14,15)$. A brain capillary has an endothelial cell layer tightly surrounded by thin pericytes and the diameter is often smaller than 10 micrometers (16). Since red blood cells are around 13 micrometers in diameter and monocytes are 22 (17), cells shinny through the dilated thin tubules in a physiological state. The mean distance 
from the center of the neuronal somata to the closest microvessel is 15 microns (14). Neurons need a supply of nutrients and oxygen from vessels and would be affected by any defect in the immediate vasculature.

\section{Radiation sensitivity of vascular cells}

The endothelial cells of brain capillaries and their surrounding pericytes are known to display certain characteristics. Although these characteristics are not fully understood, studies have described their relationship to radiation.

\subsection{Cell viability}

AA study compared rat primary cerebromicrovascular endothelial cells in culture to neurons, microglia, and astrocytes in terms of their sensitivity to radiation. The endothelial cells had marked sensitivity to radiation (a $\sim 2$-fold larger number of dead cells) (18).

\subsection{Angiogenesis}

Angiogenesis, i.e., the making of new blood vessels, could play an important role in natural cognition. Physical exercise is known to have beneficial effects on mental health (19) to have anti-depressant action (20), and on learning ability (21). In these instances, angiogenesis seems to be indispensable because injection of angiogenesis inhibitors canceled out the effects of exercise (20).

After irradiation, angiogenesis, i.e. CD31-positive capillary density, decreases substantially in laboratory mice (22) and is accompanied by learning deficits (23). Thus, a deficit in angiogenesis may cause cognitive decline. However, this decline might be inevitable for patients who have a tumor since the target for RT is not merely tumor cells but also angiogenesis inside the tumor. Limiting irradiation sites to areas around tumors seems to be the most ideal way to resolve this problem. Bevacizumab (Avastin) and other recent anti-cancer drugs inhibits angiogenesis, so this type of drugs should be used with caution in combination with RT (O).

\subsection{Transcriptome profiles}

A study reported on the transcriptome profiles of mouse brain tissue after whole-body irradiation. The study noted that the most altered genes involved ion channels, longterm potentiation, depression, and vascular damage (22).

\section{Similarity and relationship to forms of senile dementia including Alzheimer's disease}

Many possible remedies of irradiation-induced cognitive decline and precautions to limit that decline have been proposed and used $(24,25)$ in patients and animals. Two effective remedies were memantine $(26,27)$ and donepezil $(28,29)$. Both are drugs to treat Alzheimer's disease and both have different targets of action (30).

Some recent studies of Alzheimer's disease have suggested that vascular defects in small capillaries may play a central role (31-34). In addition, cognitive decline as a result of radiation and cognitive decline as a result of senile dementia $(25,35)$ seem to have common features. Animal models using radiation $(1,5,10)$ would be of great benefit if they can serve as a general model of dementia because they can be produced in young animals in a short period of time.

\section{Conclusion}

Cognitive deficits after whole-brain radiation therapy for cancer should be studied in light of vascular damage along with forms of dementia, including Alzheimer's disease.

\section{Acknowledgements}

This work was supported by a Grant-in Aid for Scientific Research (A, 26250041) from the Ministry of Education, Science, Sports and Culture and a Core Research for Evolutionary Science and Technology grant from the Japan Science and Technology Agency.

\section{References}

1. Liu Y, Xiao S, Liu J, Zhou H, Liu Z, Xin Y, Suo WZ. An experimental study of acute radiation-induced cognitive dysfunction in a young rat model. AJNR Am J Neuroradiol. 2010; 31:383-387.

2. Meyers CA, Brown PD. Role and relevance of neurocognitive assessment in clinical trials of patients with CNS tumors. J Clin Oncol. 2006; 24:1305-1309.

3. Khasraw M, Posner JB. Neurological complications of systemic cancer. Lancet Neurol. 2010; 9:1214-1227.

4. Chang EL, Wefel JS, Hess KR, Allen PK, Lang FF, Kornguth DG, Arbuckle RB, Swint JM, Shiu AS, Maor $\mathrm{MH}$, Meyers CA. Neurocognition in patients with brain metastases treated with radiosurgery or radiosurgery plus whole-brain irradiation: A randomised controlled trial. Lancet Oncol. 2009; 10:1037-1044.

5. Zhou H, Liu Z, Liu J, Wang J, Zhou D, Zhao Z, Xiao S, Tao E, Suo WZ. Fractionated radiation-induced acute encephalopathy in a young rat model: Cognitive dysfunction and histologic findings. AJNR Am J Neuroradiol. 2011; 32:1795-1800.

6. Jeyaretna DS, Curry WT, Jr., Batchelor TT, StemmerRachamimov A, Plotkin SR. Exacerbation of cerebral radiation necrosis by bevacizumab. J Clin Oncol. 2011; 29:e159-162.

7. Chen JH, Yen YC, Liu SH, Lee FP, Lin KC, Lai MT, Wu CC, Chen TM, Yuan SP, Chang CL, Wu SY. Dementia risk in irradiated patients with head and neck cancer. Medicine (Baltimore). 2015; 94:e1983.

8. Schatz J, Kramer JH, Ablin A, Matthay KK. Processing 
speed, working memory, and IQ: A developmental model of cognitive deficits following cranial radiation therapy. Neuropsychology. 2000; 14:189-200.

9. Snyder JS, Hong NS, Mcdonald RJ, Wojtowicz JM. A role for adult neurogenesis in spatial long-term memory. Neuroscience. 2005; 130:843-852.

10. Rola R, Raber J, Rizk A, Otsuka S, Vandenberg SR, Morhardt DR, Fike JR. Radiation-induced impairment of hippocampal neurogenesis is associated with cognitive deficits in young mice. Exp Neurol. 2004; 188:316-330.

11. Monje ML, Palmer T. Radiation injury and neurogenesis. Current opinion in neurology. 2003; 16:129-134.

12. Peiffer AM, Leyrer CM, Greene-Schloesser DM, Shing E, Kearns WT, Hinson WH, Tatter SB, Ip EH, Rapp SR, Robbins ME, Shaw EG, Chan MD. Neuroanatomical target theory as a predictive model for radiation-induced cognitive decline. Neurology. 2013; 80:747-753.

13. Otsuka S, Coderre JA, Micca PL, Morris GM, Hopewell JW, Rola R, Fike JR. Depletion of neural precursor cells after local brain irradiation is due to radiation dose to the parenchyma, not the vasculature. Radiat Res. 2006; 165:582-591.

14. Tsai PS, Kaufhold JP, Blinder P, Friedman B, Drew PJ, Karten HJ, Lyden PD, Kleinfeld D. Correlations of neuronal and microvascular densities in murine cortex revealed by direct counting and colocalization of nuclei and vessels. J Neurosci. 2009; 29:14553-14570.

15. Wu J, Guo C, Chen S, Jiang T, He Y, Ding W, Yang Z, Luo Q, Gong H. Direct 3D analyses reveal barrel-specific vascular distribution and cross-barrel branching in the mouse barrel cortex. Cerebral Cortex. 2016; 26:23-31.

16. Burke MJ, Nelson L, Slade JY, Oakley AE, Khundakar AA, Kalaria RN. Morphometry of the hippocampal microvasculature in post-stroke and age-related dementias. Neuropathol Appl Neurobiol. 2014; 40:284295.

17. Mainland D, Coady BK. The investigation of cell size with special reference to the human lymphocyte. J Anat. 1938; 72:374-398.

18. Ungvari Z, Podlutsky A, Sosnowska D, Tucsek Z, Toth P, Deak F, Gautam T, Csiszar A, Sonntag WE. Ionizing radiation promotes the acquisition of a senescenceassociated secretory phenotype and impairs angiogenic capacity in cerebromicrovascular endothelial cells: Role of increased DNA damage and decreased DNA repair capacity in microvascular radiosensitivity. J Gerontol A Biol Sci Med Sci. 2013; 68:1443-1457.

19. Matta Mello Portugal E, Cevada T, Sobral MonteiroJunior R, Teixeira Guimaraes T, Da Cruz Rubini E, Lattari E, Blois C, Camaz Deslandes A. Neuroscience of exercise: From neurobiology mechanisms to mental health. Neuropsychobiology. 2013; 68:1-14.

20. Kiuchi T, Lee H, Mikami T. Regular exercise cures depression-like behavior via VEGF-Flk-1 signaling in chronically stressed mice. Neuroscience. 2012; 207:208217.

21. Kerr AL, Steuer EL, Pochtarev V, Swain RA. Angiogenesis but not neurogenesis is critical for normal learning and memory acquisition. Neuroscience. 2010; 171:214-226.

22. Warrington JP, Csiszar A, Johnson DA, Herman TS, Ahmad S, Lee YW, Sonntag WE. Cerebral microvascular rarefaction induced by whole brain radiation is reversible by systemic hypoxia in mice. Am J Physiol Heart Circ
Physiol. 2011; 300:H736-744.

23. Warrington JP, Csiszar A, Mitschelen M, Lee YW, Sonntag WE. Whole brain radiation-induced impairments in learning and memory are time-sensitive and reversible by systemic hypoxia. PloS one. 2012; 7:e30444.

24. Davis J, Ahlberg FM, Berk M, Ashley DM, Khasraw M. Emerging pharmacotherapy for cancer patients with cognitive dysfunction. BMC Neurol. 2013; 13:153.

25. Attia A, Page BR, Lesser GJ, Chan M. Treatment of radiation-induced cognitive decline. Curr Treat Options Oncol. 2014; 15:539-550.

26. Brown PD, Pugh S, Laack NN, Wefel JS, Khuntia D, Meyers C, Choucair A, Fox S, Suh JH, Roberge D, Kavadi V, Bentzen SM, Mehta MP, Watkins-Bruner D. Memantine for the prevention of cognitive dysfunction in patients receiving whole-brain radiotherapy: A randomized, double-blind, placebo-controlled trial. Neuro Oncol. 2013; 15:1429-1437.

27. Slade A, Stanic S. The impact of RTOG 0614 and RTOG 0933 trials in routine clinical practice: The US Survey of Utilization of Memantine and IMRT planning for hippocampus sparing in patients receiving whole brain radiotherapy for brain metastases. Contemp Clin Trials. 2015; 47:74-77.

28. Rapp SR, Case LD, Peiffer A, Naughton MM, Chan MD, Stieber VW, Moore DF, Jr., Falchuk SC, Piephoff JV, Edenfield WJ, Giguere JK, Loghin ME, Shaw EG. Donepezil for irradiated brain tumor survivors: A phase III randomized placebo-controlled clinical trial. J Clin Oncol. 2015; 33:1653-1659.

29. Shaw EG, Rosdhal R, D'agostino RB, Jr., Lovato J, Naughton MJ, Robbins ME, Rapp SR. Phase II study of donepezil in irradiated brain tumor patients: Effect on cognitive function, mood, and quality of life. J Clin Oncol. 2006; 24:1415-1420.

30. Mccaffrey P. Alzheimer's drug helps brain function after radiotherapy. Lancet Oncol. 2006; 7:371.

31. Drachman DA. The amyloid hypothesis, time to move on: Amyloid is the downstream result, not cause, of Alzheimer's disease. Alzheimers Dement. 2014; 10:372380 .

32. Giwa MO, Williams J, Elderfield K, Jiwa NS, Bridges LR, Kalaria RN, Markus HS, Esiri MM, Hainsworth AH. Neuropathologic evidence of endothelial changes in cerebral small vessel disease. Neurology. 2012; 78:167174.

33. Okamoto Y, Yamamoto T, Kalaria RN, Senzaki H, Maki T, Hase Y, Kitamura A, Washida K, Yamada M, Ito $\mathrm{H}$, Tomimoto $\mathrm{H}$, Takahashi $\mathrm{R}$, Ihara M. Cerebral hypoperfusion accelerates cerebral amyloid angiopathy and promotes cortical microinfarcts. Acta Neuropathol. 2012; 123:381-394.

34. Wang F, Guo X, Shen X, Kream RM, Mantione KJ, Stefano GB. Vascular dysfunction associated with type 2 diabetes and Alzheimer's disease: A potential etiological linkage. Med Sci Monit Basic Res. 2014; 20:118-129.

35. Cherry JD, Liu B, Frost JL, Lemere CA, Williams JP, Olschowka JA, O'banion MK. Galactic cosmic radiation leads to cognitive impairment and increased abeta plaque accumulation in a mouse model of Alzheimer's disease. PloS one. 2012; 7:e53275.

(Received January 4, 2016; Revised February 6, 2016; Accepted February 6, 2016) 